\title{
Who Was Afraid of Pregnancy Tests? Gestational Information and Reproduction Policies in France (1920-50)
}

\author{
FABRICE CAHEN * \\ Institut national d'études démographiques (INED), F-75020 Paris, France
}

\begin{abstract}
Though resulting from a long-term process, the need to manage pregnancies both medically and bureaucratically became a state concern, especially from the 1920 s onwards. A woman's official obligation to notify the state of her pregnancy (and therefore to know it on time) goes beyond a matter of biopolicies and poses a range of contradictions. 'Pregnant or not?' - as an issue of knowledge - is a powerful tool for apprehending the tensions between individual freedom, privacy, institutional requirements and professional powers.

In order to better understand the historical meaning of pregnancy diagnostics in mid-twentieth-century France, this paper combines three dimensions: uncertainty and its management; the informational asymmetry between institutional agents and women; and the diachronic dimension of gestation. Writing this history sheds more light on an apparent paradox: while knowing and notifying one's own pregnancy became a duty, the tools that could help women eliminate some doubt right from the first months of their pregnancy - in particular the innovation of laboratory diagnosis - was seen as a danger. When, in 1938, private laboratories began publishing advertisements for the laboratory test in the most widely-read newspapers, tending to reframe it as a commercial service, the anti-abortion crusade was increasing its propaganda and its political pressure. This crusade's legal victory proved incomplete, but for a long time some of the most conservative physicians recommended great parsimony in prescribing testing. Combined with reducing the legal time limit for notification, this conflict shows how the state injunctions towards women could look like a 'double bind'.
\end{abstract}

Keywords: Biopolicies, Pregnancy test, Abortion, Uncertainty, Agency

\footnotetext{
* Email address for correspondence: fabrice.cahen@ined.fr
}

I am grateful to Cyrille Jean, Jesse Olszynko-Gryn, Caroline Rusterholz and the two anonymous referees of this paper for their stimulating comments and relevant advice. The author and publishers acknowledge the following sources of copyright material and are grateful for the permissions granted. While every effort has been made, it has not always been possible to identify the sources of all the material used, or to trace all copyright holders. If any omissions are brought to our notice, we will be happy to include the appropriate acknowledgements on reprinting and in the next update to the digital edition, as applicable. 
Today's high level of medical surveillance and bureaucratic imperatives surrounding reproduction seems to be a relatively recent product of modern 'risk societies'. It is possible, however, to construct longer-term histories of the medicalisation of pregnancy and childbirth. On the one hand, we have the 'heroic' narrative of public health and decreasing mortality that runs from the Pasteurian era up to globalised Western prenatal and birth practices. On the other, there are Foucauldian and feminist critiques of the regulation and control of private and bodily behaviours. In analysing the history of reproduction through the interaction of state expansion and the medicalisation of society, it becomes impractical to simply favour one or the other of these two opposing frameworks, as they represent two sides of a devalued coin: positivist naivety on one face, and radical anti-medical and anti-institutional sentiments on the other. ${ }^{1}$ Instead, it would be more effective to carefully reconstruct the everyday grass-roots level creation of the social state (including family welfare and health policies). To do so, it is necessary to reckon first with the complex processes and dynamic tensions between individual privacy, institutions, technologies and professional powers.

Previous research on birth policies in France has outlined the emergence of a specific injunction, namely, a woman's 'duty of knowing' her own pregnancy. ${ }^{2}$ This injunction might have been a keystone of the official management of pregnancy, which emerged in Early Modern times and increasingly manifested as a medically-based state policy roughly around the 1920s. Studying such an issue must not omit women's attitudes regarding their own gestations; indeed, the question of 'pregnant or not' pertains to three different dimensions: Am I pregnant? Is a given woman pregnant? Which women are pregnant in a given population? In the analytic model I have designed, the history of reproductive policies is not only a matter of gender, inequalities and social order but also a history of uncertainty, self-monitoring and existential control. ${ }^{3}$ Taken to the indistinct boundaries between sociology, psychology and biology, the historian cannot ignore the materiality of bodies or 'bodily techniques' (as French sociologist Marcel Mauss called them), both of which are at once constraining elements and sites of agency. ${ }^{4}$

\footnotetext{
${ }^{1}$ Medicalisation can be understood as 'the extension of medical jurisdiction over health itself': Adele E. Clarke, Janet K. Shim, Laura Mamo, Jennifer Ruth Fosket and Jennifer R. Fishman, 'Biomedicalization: Technoscientific Transformations of Health, Illness, and US Biomedicine', American Sociological Review, 68 (2003), 161-94.

2 A more extended reflection on the 'duty of knowing' has been offered in: Fabrice Cahen and Silvia Chiletti, 'Connaître précocement sa grossesse : réflexions historiques sur une prescription ambivalente', Clio. Femmes, Genre, Histoire, 48, Autumn 2018. This female duty derived from the modern 'Family-State Compact': Sarah Hanley, 'Engendering the State: Family Formation and State Building in Early Modern France', French Historical Studies, 16, 1 (1989), 4-27. In nineteenth- and twentieth-century health, pronatalist and moral policies relieved the concern about unknown pregnancies, which is still a major issue in improving abortion access and antenatal care today.

${ }^{3}$ On cognition and uncertainty in reproductive life and medicine: Éric Brian and Marie Jaisson, Le sexisme de la première heure. Hasard et sociologie (Paris: Seuil, 2007); Renée C. Fox, 'Medical uncertainty revisited', in G. Albrecht, R. Fitzpatrick and S. Scrimshaw (eds), Handbook of Social Studies in Health and Medicine (London: Sage. Kottak, C. P., 2000), 409-25; Aaron V. Cicourel, Le raisonnement médical. Une approche socio-cognitive (Paris: Seuil, 2002); Sciences sociales et santé, 1, 26 (2008); Michelle Murphy, Sick Building Syndrome and the Problem of Uncertainty: Environmental Politics, Technoscience, and Women Workers (Durham: Duke University Press, 2006); Cathy McClive, 'The Hidden Truths of the Belly: The Uncertainties of Pregnancy in Early Modern Europe', Social History of Medicine, 15, 2 (2002), 209-27; Jürgen Schlumbohm, 'Les limites du savoir: médecins et femmes enceintes à la maternité de l'Université de Göttingen aux alentours de 1800', Revue d'histoire moderne et contemporaine, 52, 1 (2005), 64-94.

${ }^{4}$ For relevant reflections on the material body: Dominique Memmi, Dominique Guillo and Olivier Martin, Corporéité et sciences sociales (Paris: Éditions de l'EHESS, 2009); Alexandre Jaunait, Michal Raz and Eva Rodriguez, 'La biologisation de quoi ?', Genre, sexualité \& société, 12 (2014). Despite its positivism and
} 
The period examined in this paper - namely the first part of the twentieth century saw a backlash against the moral and demographic changes that had been denounced since the 1870s, and more especially during the 'disruptive' context of the Great War, as well as the popularisation of knowledge about sexuality and reproduction in parallel with advances in fertility control. We have several substantial studies of the Law of 1920 condemning neo-Malthusianism and banning birth-control information of any kind, and the Law of 1923 making punishment for abortion easier. Much has been written about the Family Code (Code de la famille) of July 1939, which contented - as a result of several decades of intense pronatalist lobbying - a wide range of provisions regarding citizenship, adoption, family incentives and abortion, and, obviously, about the Vichy policies of moral order which newly aggravated anti-abortion policies. ${ }^{5}$ However, two aspects that have been comparatively neglected are the material and social history of the 'biological' test for pregnancy (a German innovation introduced into the field of French medicine during the late 1920s) and the broader issue of gestational information at the level of the individual woman. Concentrating on pregnancy 'diagnosis' - an apparently minor event - sheds new light on the rich social interplays that are at stake in the social production of human life.

Two questions initiated this research: Why did some influential pronatalist activists prevent the diffusion of biological diagnosis after 1938 even though there was no initial controversy around the 'Aschheim-Zondek test', as the first reliable hormone test for pregnancy was called, and its French counterparts? And, were the opponents of early diagnosis right to think that biological testing was becoming at once a widespread service and an effective support for female autonomy? I examine several sets of documents to address these questions. Some are published sources related to pregnancy issues: legislation on pregnancy notification and on pregnancy diagnosis, medical literature, articles from general and women's newspapers that were excerpted from Gallica (the French National Library's digital collection). Others are archival materials collected in the course of previous research on anti-abortion policies as they relate to pronatalist lobbying and to the French medical professional organisation known as the Ordre national des médecins.

The first part of this paper will examine the making of a 'duty to know' and give an overview of the means for detecting early pregnancies in a period of rapid biomedical progress. The second section will explore the social uses of the hormone test after its introduction into clinical practice in the 1930s. Finally, I will study the impact of the antiabortion 'crusade' and the kind of regulation it generated, highlighting the dead ends of this limited and controlled access to individual gestational information. We will see that it was impossible in practical terms to draw a clear line between acceptable and inacceptable biodiagnostic uses of the pregnancy test in the early years of its clinical adoption.

polemical criticism of feminist interpretations, Shorter's famous book has the virtue of taking seriously some realities that were traditionally avoided by historians; he pointed out the constraints that the female body can generate in its own right. See Edward Shorter, A History of Women's bodies (New York: Basic Books, 1982).

${ }^{5}$ For the state regulation of reproduction in France (1918-50): Marc Boninchi, Vichy et l'Ordre moral (Paris: Presses universitaires de France, 2005); Fabrice Cahen, Gouverner les mours. La lutte contre l'avortement en France, 1890-1950 (Paris: Ined, 2016); Cyril Olivier, Le Vice ou la Vertu. Vichy et les politiques de la sexualité, 1940-44 (Toulouse: Presses universitaires du Mirail, 2005); Jean E. Pedersen, 'Regulating Abortion and Birth Control: Gender, Medicine, and Republican Politics in France, 1870-1920', French Historical Studies, 19, 3 (1996), 673-98; Francis Ronsin, La grève des ventres. Propagande néo-malthusienne et baisse de la natalité en France (XIXe-XXe siècle) (Paris: Aubier, 1980); Françoise Thébaud, Quand nos grands-mères donnaient la vie. La maternité en France dans l'entre-deux-guerres (Lyon: Presses universitaires de Lyon, 1986). 


\section{Knowing Pregnancy: Between Official Requirements and Personal Motivations}

The propensity for more and more reproductive awareness and self-monitoring, as a historical process, makes it necessary to reckon with individual curiosity, on the one hand, and social norms and pronatalist policies, on the other. Rather than determining when, how and why it became a social habit to answer the question 'pregnant or not?', this section aims to trace the increasing institutionalisation of a formal procedure - pregnancy notification - by identifying meaningful landmarks and pivotal moments. To simplify this aspect, I propose a threefold schema: the state and its will to oversee reproductive behaviours; medical professionals, their professional curiosity and their fear of incorrect diagnoses; and women as agents in their capacity to self-diagnose as well as to actively seek out medical and other forms of information and advice.

\section{The 'Pregnant Woman' and the Law up to the 1930 s}

King Henri II's Edict of 1557 establishing a woman's duty to notify the state of her pregnancy is generally considered to be the first national state regulation making pregnancy a subject of official information, if not an administrative category. Among the various reasons behind this royal decision, the most explicit purpose was to prevent infanticide, a crime that deprived the new-born of any possibility of baptism. In virtue of the 1557 text, notification was not compulsory per se, but the mother of an infant found dead was presumed criminal if she had not declared her pregnancy, especially if she was unmarried. In practice, up to the nineteenth century, mandated notification primarily functioned as a means of protecting pregnant women who anticipated conflict or litigation after childbirth, in particular contested fatherhood. The notification essentially became a matter of civil law. ${ }^{6}$

The issue evolved fundamentally in the first half of the twentieth century with the expansion of mother-and-child programme policies that combined social, hygienist and moral purposes and led to a series of regulations designed to safeguard pregnant women and to assist mothers. ${ }^{7}$ Each new regulation imposed a stricter schedule of obligations. According to the 1913 law on maternity leave compensation, a woman was expected to show evidence in the form of a medical certificate, but she remained free to notify her pregnancy at any stage. Moreover, the law stipulated only the need to be medically examined 'before the term of pregnancy'. Later decades, during which the variable and uncertain length of human gestation was still debated, saw the establishment of a defined administrative schedule. The laws of 1928 and 1930 on social insurance allocated reimbursements for medical expenses and daily indemnities related to antenatal care, childbirth and breastfeeding. These were supplemented by a circular of 1931, which encouraged women to send notification of their pregnancies 'as soon as it is known'. Nevertheless, the legal deadline was set at three months before the due date, with a final

\footnotetext{
${ }^{6}$ Hanley, op. cit. (note 2); Marie-Claude Phan, 'Les déclarations de grossesse en France, XVIe-XVIIIe siècles. Essai institutionnel', Revue d'histoire moderne et contemporaine, 22, 1 (1975), 61-88. For a comparative perspective (seventeenth-century infanticide laws in England, Wales, and Scotland): Anne-Marie Kilday, History of Infanticide in Britain, c. 1600 to the Present (Basingstoke: Palgrave Macmillan, 2013).

${ }^{7}$ For the history of maternal rights in France, more generally: Anne Cova, Maternité et droit des femmes en France (XIXe-XXe siècles) (Paris: Anthropos, 1997) and Susan Pedersen, Family, Dependence and the Origins of the Welfare State: Britain and France, 1914-45 (Cambridge: Cambridge University Press, 1993); Gisela Bock, Pat Thane (eds), Maternity and Gender Policies: Women and the Rise of the European Welfare State, 1880s1950s (London: Routledge, 1994).
} 
notification set at six weeks before the expected delivery date and a commitment to stop working. According to the 1931 circular, it made no sense to take out maternity insurance before the date when pregnancy could be 'medically presumed', namely the fifteenth week. The editors might have considered the frequency of early miscarriage, knowing that spontaneously interrupted pregnancies were theoretically covered by maternity insurance. Each Caisse d'assurance maladie - the paying entities - could fix their own legal delay, which was four months before childbirth in Seine-et-Oise, for instance. ${ }^{8}$

\section{Diagnosing Pregnancy}

What did it mean to know one's own pregnancy - and to know it on time - in these different periods from the sixteenth century to the 1930s? Current academic discussion has broadened quite a bit regarding a woman's ability to identify the signs and symptoms of her own pregnancy. Many academics have underscored the resilience of old beliefs, such as the existence of a causal link between orgasm and fertilisation and the array of magical and folkloric practices (from astrology to uroscopy), to substantiate that, as historians, they are unconvinced about this ability. Nevertheless, evidence found in the archives of intimacy suggests that, even from the Early Modern age, many women were in fact able to detect gestation at an apparently early stage, thanks to their empirical knowledge of amenorrhea (absence of menstruation), 'sympathetic signs' (morning sickness, breast changes, and so on) and quickening (the sensation of foetal movement in the womb). This was especially true for women who had previously experienced pregnancy and knew what it felt like. ${ }^{9}$

As medicine extended its realm into female health and human reproduction around the eighteenth century, doctors increasingly acquired the skill to diagnose pregnancy. The establishment of reliable and ubiquitous signs of pregnancy had become part of their quest for professional legitimacy and superiority over midwives, herbalists and others. It was, above all, a means to prevent some dramatic mistakes: as medicine became more interventionist, unknown or hidden gestations could transform an ordinary medical procedure into a criminal act. Around 1800, doctors faced the risk of performing bloodletting on and prescribing drugs to possibly pregnant women. In the following

\footnotetext{
${ }^{8}$ Quoted legal texts are excerpted from the Journal officiel de la République française. Lois et décrets: Law of 30 July 1913 and circular of 9 August 1913; Law of 5 April 1928 modified by the Law of 30 April 1930; Circular from the Ministry of Work to the prefects, 21 March 1931. Additional legal information comes from: Georges Buisson, Confédération générale du travail, Les Assurances sociales. L’Assurance maternité. Manuel pratique suivi des lois, décrets et circulaires concernant l'assurance-maternité, Versailles, Paris (1932), 10-11; Hippolyte Durand, Claude-Joseph Green, Cte de Saint-Marsault and J.V. Aubernon, 'Rapports du préfet et de la commission départementale (département de Seine-et-Oise), Versailles' (1944). Defining the due date accurately is rendered impossible by ignorance about the moment of fertilisation (in vivo), along with the absence of a standard duration of human pregnancy. According to the early twentieth-century physicians (see: 'Grossesse', Larousse medical dictionary, 1924), the mean length of pregnancy was fourteen weeks (280 days), with a margin of error of from twenty to twenty-five days. The prestigious professors Budin and Pinard estimated this physiological duration as nine months and five days, or thirty-seven weeks. From a legal standpoint, the Napoleonic Civil Code was used as a reference, and it postulated that known medical observations indicated that pregnancy never exceeded 300 days. Therefore, this length determined the minimum interval a woman had to respect before she could remarry (called 'délai de viduité'). After this interval, a new husband could not accuse the previous one of being responsible for the pregnancy. Contrary to their British counterparts, French feminists did not protest the required notification. On this last point, see Salim Al-Gailani, "The mothers of England object to it": The notification of Pregnancy in Early Twentieth Century Britain', Society for the Social History of Medicine, University of Kent, 9 July 2016.

${ }^{9}$ Barbara Duden, Disembodying Women: Perspectives on Pregnancy and the Unborn (Cambridge, MA: Harvard University Press, 1993); Cornelie Usborne, Cultures of Abortion in Weimar Germany (New York: Berghahn, 2007); Emmanuelle Berthiaud, 'Grossesse désirée, grossesse imposée: le vécu de la grossesse aux XVIIIeXIXe siècles en France dans les écrits féminins privés', Histoire, économie \& société, 28, 4 (2009), 35-49; and Enceinte. Une histoire de la grossesse entre art, histoire et société (Paris: La Martinière, 2013).
} 
decades, the development of surgical interventions such as curettage, laparotomy and hysterectomy increased the risk of inducing miscarriage in cases of undetected gestation. French practitioners worried that deceptive patients could trick them into inadvertently performing abortions. Several circulating stories haunted professional discussions. A famous 1897 case, for instance, involved the surgeon Boisleux being accused of criminal abortion after he had performed a uterine curettage on a Mrs Thompson to cure a metritis (inflammation of the uterine wall). Boisleux did not check that the womb was empty and his patient turned out to be pregnant. She haemorrhaged and a foetus was partly expulsed. Boisleux then opted for a laparotomy, but Mrs Thompson died some hours later of complications. The surgeon was found guilty and jailed for five years, even though there was no proof that he had planned to abort a foetus. ${ }^{10}$

The notorious Boisleux case highlighted the difficult task forensic experts (in this case the famous Paul Brouardel) faced when confronted with abortion and, in some cases, also maternal death. More generally, the medico-legal dimension of the 'pregnant or not' question was particularly exacerbated in the nineteenth century because the repression of infanticide and abortion frequently brought judicial authorities into direct confrontation with women who denied being or having recently been pregnant. Depending on the category of the alleged crime, the precise conditions of the violation and the strength of evidence in the hands of the court, defendants resorted to several strategies. Either they claimed total ignorance of the pregnancy right up until childbirth took them by surprise, or they argued that, having not known the moment when they would deliver, they had been unprepared for a safe delivery and notably failed to seek out a midwife. Forensic scientists and other medical experts claimed that establishing pregnancy was one of the greatest challenges they could face. ${ }^{11}$

Pursuing the dual purpose of reliable and early diagnosis, doctors searched for better indicators than those which women could observe by themselves. Nevertheless, science did not identify any bodily manifestations which could obtain formal evidence for 'signs of certainty' before mid-term. No 'rational' sign provided any greater probability than foetal auscultation, a technique which was already available as early as 1822. 'Hégar's sign', developed in the 1880s, enabled gynaecologists to feel cervical and uterine changes, although without any certainty until late in the fourth month. Obstetrical radiography emerged after the Great War, but obtaining a reliable picture of the foetal skeleton was not possible in the earlier stages of pregnancy. What is more, even if we assume doctors had a perfectly objective and accurate method for determining whether a woman had recently been gestating, and supposing that pregnancy and/or childbirth were clearly established, it would have still been extremely complicated to prove a woman had been aware that she was carrying a foetus. Getting into the heart of hearts - the realm of subjectivity, obscure feelings and unexpressed intentions - is in essence an unreachable goal for human justice. So it is by convention that, through medico-legal experience and judicial precedent, experts defined the end of the fourth month of gestation as a turning point, what I call here the 'psychological threshold'. This delineation identified clinical signs indicating the presence of a foetus - quickening (for women) and the foetal heartbeat (for doctors) which theoretically rendered the woman conscious of her condition. Indeed, it was taken for granted, since the nineteenth century, that a 'normal' pregnant woman becomes an

10 Two opposing views on the Boisleux case: Octave Mirbeau, 'Brouardel et Boisleux', Le Journal, 25 July 1897; Paul Brouardel, L'avortement (Paris: Baillière, 1901), 163-5 and 344-65.

${ }^{11}$ Brouardel, op. cit. (note 10). 
expectant mother from the moment when she feels, instead of an uncertain pregnancy and an abstract foetus, a baby living in her womb. This moment was approximately located at mid-term. ${ }^{12}$

\section{A Market of Uncertainty}

One can assume that already in the first part of the twentieth century many women would have wanted to confirm or exclude pregnancy soon. This goes for women desiring motherhood and wishing to benefit from legal provisions as well as women who were dreading pregnancy and wishing to rule it out. For the women whose behaviours aligned more or less with the normative model promoted by public policies - anticipation and control rather than fatalism or carelessness - it may have been necessary, if not tempting, to receive valuable confirmation without waiting until mid-term. However, in at least the lower classes, the doctor was probably scarcely consulted due to a combination of modesty, financial cost and prejudices. Above all, physicians often led patients to believe that professional confidentiality would not protect them from the law. This was common knowledge and many women would have perceived it as judicially risky to seek medical confirmation of pregnancy. That being said, several alternatives existed. Studying the newspapers' classified pages offers rich information on this matter. ${ }^{13}$

Around a decade after the invention of the Aschheim-Zondek test for pregnancy in Berlin, a column in the 22 October 1938 issue of the daily Paris-Soir reveals that older techniques persisted even after the advent of new, innovative technologies. The column, labelled 'occult science' (sciences occultes), contains a series of advertisers listed by their first name ('Andrée', 'Astrid', etc.). Every one of them guarantees their skill in reading tarot cards. Among the various types of requests (love, disease, money, sex of an expected child), fortune-tellers were consulted by women seeking to know whether or not they were pregnant. Though little studied by scholars, ${ }^{14}$ an abundance of circumstantial evidence - from trials, advertisements, papers and books - points to the crucial role of clairvoyants and tarot-readers in the area of reproductive practices. This anxiety-based activity was intertwined with related businesses, insofar as tarot-readers also provided the addresses of abortionists and, in some cases, actually practised the abortion themselves. In an ironic 1943 case, a Normandy fortune-teller nicknamed 'Nana', who was suspected of performing an abortion on a client, greatly embarrassed the judges when she argued that, after all, it was nothing other than the cards that had 'proved' the reality of the supposedly interrupted pregnancy. ${ }^{15}$

\footnotetext{
12 Silvia Chiletti, 'Grossesses ignorées au prisme de l'infanticide. Savoirs médicaux et décisions de justice au XIXe?siècle', Revue d'histoire du XIXe siècle, 50 (2015), 165-79. Nowadays, obstetric ultrasound can provide certain embryonic signs from the sixth week of amenorrhea (pelvic echography) and detect heartbeats at the twelfth week (foetal Doppler).

${ }^{13}$ I consulted the daily newspapers digitalised on Gallica, by using keywords ('pregnancy', 'diagnosis', 'test', 'biological', etc.). All the main titles are available until 1944, but the relevant ads were mainly published between autumn 1938 and spring 1939.

14 But, for a discussion of psychic pregnancy confirmation in the 1920s, see Lucy Bland, "Hunnish scenes" and a "virgin birth": a 1920s case of sexual and bodily ignorance', History Workshop Journal, 73 (2012), 118-43.

15 An example of a book that teaches the card combinations for answering the 'pregnant or not' question: Armand Bourgade, Nouvel art de tirer les cartes ou La connaissance de l'avenir prédite par les cartes (précédé d'une notice historique sur les cartes et suivi de la manière de faire les réussites et d'un traité de chiromancie) (Paris: 18 (unprecised)). See also Francis Girault, Mlle Le Normand: sa biographie, ses prédictions extraordinaires, son commerce avec les personnages les plus illustres d'Europe, de la République (Paris: 1843), 163-4. 'Nana's' case was found in Le Petit Parisien, 22 January 1943. Some other reported cases in the press: Le Populaire, 1 April 1929 and 26 December 1930. In his memoirs, Dr Levi-Valensin mentions tarot-readers involved in pregnancy
} 
The 'medicine' column, which follows the 'occult' section, is divided into several subsections. It begins with a list of midwives, who indicate only their addresses. They do not allude to any illegal services in their succinct messages, but they do systematically provide the guarantee of 'discretion'. However, the most intriguing notice, placed just above the 'midwives' section, is an advertisement for Laboratory G. Cambus, a Parisian commercial laboratory, which proudly proclaims its 'biological diagnosis' practice. Thus, three categories of service share space in Paris-Soir, in other words, three kinds of uncertainty-reducing businesses: a technological laboratory at the forefront of biomedical innovation that - for a fee of 200 francs (which was equivalent to a quarter of an unskilled worker's mean monthly salary) - offers 'hospital-like' professionalism with no medical intermediaries (no prescription required); a range of magical (and more affordable) practices that were at least as good as tossing a coin; and the skills of midwives (as well as accommodating doctors), including their capacities for empathy and understanding. ${ }^{16}$

\section{Early Diagnostics in the 1930s: Uses and Abuses?}

'Pregnant or late?' It was in the two last months of 1938 that this key-question became the headline of many classified advertisements in large national dailies such as L'Humanité, Le Matin and Le Journal. Thus, it is all the more surprising that - until the mid-1960s in Britain - commercial pregnancy diagnostic services advertised only to medical professionals; even advertising to pharmacists was too controversial to be permitted, notably due to the opposition of the British Medical Association in reaction to certain advertisements in the late 1940s. Two Parisian for-profit companies massively disseminated such ads (but unfortunately left no archival trace): Laboratory G. Cambus and the 'Eyolma Centre'. Their messages emphasised rapidity (a urine sample can be tested from late menstruation and produce results in forty-eight hours), reliability, scientificity, simplicity and discretion. What is the significance of these commercial campaigns? Was hormonal pregnancy diagnosis in France an unregulated product for mass-consumption? ${ }^{17}$

The history of the pregnancy biodiagnosis is part of that of serological reactions (like the Wasserman test for syphilis) and of the development of endocrinology. It is known to date back from 1927, when the German gynaecologists Selmar Aschheim and Bernhard Zondek found that it was possible to detect the presence of a so-called 'pregnancy hormone' - since the 1940s known as 'human chorionic gonadotrophin' (hCG) - by injecting a woman's urine into the ovaries of an immature mouse. In the early 1930s, the American Maurice H. Friedman proved the advantage of substituting rabbits for mice. The test was especially reshaped by Bertold Wiesner and Francis Crew in Edinburgh in the mid-1930s: it proved to be an efficient tool for differential diagnosis in pathological cases, such as

matters in the mid-twentieth century: Georges Lévi-Valensin, Je suis un avorteur (Paris: Filippachi, 1974). The importance of astrologers in private life is at the core of the fascinating 'Casebooks project' (Simon Forman's and Richard Napier's medical records, 1596-1634): http://www.magicandmedicine.hps.cam.ac.uk/.

16 Paris-Soir, 22 October 1938; L'Humanité, 26 November 1938. Auguste Brindeau and Hermann Hinglais, 'De l'inefficacité et des inconvénients du décret du 18 mai 1940 relatif à l'utilisation des méthodes biologiques de diagnostic de la grossesse. Proposition d'une modification profonde de ce décret', Annales de médecine légale, session of 12 November 1945, 183-93.

${ }^{17}$ Le Journal, 6 December 1938; Jesse Olszynko-Gryn, 'Pregnancy Testing in Britain, c. 1900-67: Laboratories, Animals and Demand from Doctors, Patients and Consumers' (unpublished PhD thesis: (Cambridge, 2014), 177-203. For more developments on the scientific context and the numerous tensions at play: Adele E. Clarke, Disciplining Reproduction: American Life Scientists and the 'Problem of Sex' (Berkeley: University of California Press, 1998). 
cancers and hormonal deficiencies potentially inducing miscarriage. Although their role is little known, a handful of French and Belgian obstetricians and biologists - Lucien Brouha and his daughter Adèle Brouha, the couple Marguerite and Hermann Hinglais and Henri Simmonet - were important contributors to research on the hormonal diagnosis of pregnancy, and their involvement led to a continued quest for better diagnostic skills and techniques. Instead of using immature female mice, as in the standard Aschheim-Zondek test, they developed several variants in which they used immature male mice and adult male and female rabbits. ${ }^{18}$

In retracing the history of the test through the 1930s, one detail clearly stands out: despite the growing obsession with procreative issues under the late Third Republic, these French and Belgian pioneers did not face any controversy in carrying out their activity and the medical and public hygiene authorities validated hormonal testing with no reluctance. Indeed, the possibility of establishing 'objective signs of pregnancy' during the second month sparked enthusiasm, even though the technique needed improvement. The Brouhas, the Hinglais' and Simmonet's experiments were carried out at the Clinique Tarnier under the auspices of two prestigious and influential obstetricians who were both fellows of the Academy of Medicine, namely Paul Bar and his close friend and successor as chief of service Auguste Brindeau. Other attempts at improving the technique were carried out in several hospital maternity clinics in Paris (Lariboisière, St-Antoine) and Lyon. It is important to indicate that there was no barrier between public service and for-profit activities. Hermann Hinglais headed his own commercial laboratory and was an actor in the growing folliculin market, which may explain his lack of reluctance in promoting early diagnosis. $^{19}$

The risk of uncontrolled application for - if not by - women could not be ignored. However it was scarcely alluded to. References to induced abortion are almost nonexistent in the scientific papers of the time - except for some extremely brief and rare allusions to a potential use of the test in cases where a medically indicated ('therapeutic') abortion was contemplated. Since biomedical specialists viewed the hormonal test as a tool for supporting doctors, whether for therapeutic or medico-legal purposes, they did not foresee any moral controversy. As pointed out by J. Olszynko-Gryn, after several years of experimentation and the persistent problem of 'false positives' and 'false negatives', the

\footnotetext{
${ }^{18}$ On the history of pregnancy testing, particularly in Britain: Jesse Olszynko-Gryn, 'The Demand for Pregnancy Testing: The Aschheim-Zondek Reaction, Diagnostic Versatility and Laboratory Services in 1930s Britain', Studies in History and Philosophy of Biological and Biomedical Sciences, 47 (2014), 233-47 and 'The Feminist Appropriation of Pregnancy Testing in 1970s Britain', Women's History Review (2017). The problem of sensitivity (false positive) and specificity (false negative) is a central epistemological issue in the social history of medicine, from Ludwik Fleck to Ilana Löwy; see for example, Ilana Löwy, “A river that is cutting its own bed": The Serology of Syphilis between Laboratory, Society and the Law', Studies in History and Philosophy of Biological and Biomedical Sciences, 33 (2004), 509-24. A comparison of doctors' attitudes towards the imprecisions of Wasserman test and the Aschheim-Zondek reaction is beyond the scope of this paper.

${ }^{19}$ Lucien Brouha, Henri Simonnet and Hermann Hinglais, 'L'action de l'urine de femme enceinte sur le tractus génital de la souris et en particulier de la souris mâle. Son utilisation pour le diagnostic biologique de la grossesse. Remarques sur quelques conclusions à en tirer pour la physiologie gravidique', Bulletin de l'Académie de médecine, 28 January 1930 session; M.H. Pigeaud, 'Réaction de Zondek et Aschheim. Causes d'erreur. Résultats. Technique', Lyon médical, 24 December 1933; Maurice Rives, Un nouveau test de grossesse: la réaction des mélanophores sur la grenouille hypophysectomisée (Paris, Perpignan: 1947); Paul Devilliers, 'Le diagnostic de la grossesse en médecine légale et particulièrement les méthodes biologiques' (unpublished medical thesis: Paris, 1950); Pierre Lantuéjoul, 'Notice nécrologique sur M. Brindeau', Bulletin de l'Académie de médecine, 22 November 1955. Hinglais' laboratory advertisements were published in scientific reviews such as: Comptes rendus de la Société française de gynécologie, January 1949.
} 
actual clinical applications of the test had deviated from those it was initially designed for. Rather than confirming an actual normal pregnancy in a healthy woman, the main applications upon which the patient's health depended were for establishing false or abnormal pregnancies, for diagnosing moles or placental cancers, preventing miscarriages and detecting ectopic pregnancies. What the promoters particularly highlighted was the medico-legal relevance of confirming or ruling out gestation. It was presented as an indispensable tool for civil cases (contested paternities, inheritance issues and faking pregnancy for blackmail) and for criminal judicial cases (pregnancy from rape, dubious accusations of abortion or infanticide and determining prison sentences). Forensic scientist C. Simonin even wondered if the test could be used in criminal abortion cases in order to bypass the argument of 'impossible crime' in the absence of any signs of clinical pregnancy. In fact, Simonin believed that when abortion attempts are both early and deadly for the mother, the Aschheim-Zondek was less relevant than histological diagnosis (villus examination). Above all, the test was promoted for issues involving the practitioner's civil and penal liability, in short, surgical interventions. ${ }^{20}$

An episode that occurred in 1936 mirrors the ongoing systematisation. A court order was required against the Durupt laboratory, which was accused of protocol failure leading to a misdiagnosis of extra-uterine pregnancy and unnecessary surgical treatment in a woman who was not even pregnant. The reason why the lab was considered at fault is that by then a positive test was recognised as scientific evidence. ${ }^{21}$

I nevertheless found a few notable exceptions to this overall silence regarding nonmedical uses. In Dr Martinez-Prieto's 1934 doctoral dissertation, which was supervised by Brindeau, he mentioned a potential application which could be described in terms of 'consumer convenience': reassuring a woman 'who passionately desires to have a child' and feels too anxious about the possible loss of her foetus, notably when clinical evidence is inconclusive for physiological reasons (obesity, dysmennorrhea or other). MartinezPrieto admitted that the numerous advantages of the hormonal test did not exclude a 'possible drawback': in obtaining very early information, some women could be less reluctant to seek abortion. Dr Théodore Fraenkel's statements were more disruptive. Fraenkel (1896-1964) was a left-wing general practitioner still known today as a writer associated with the surrealist movement. In a 1933 issue of the newspaper Marianne, he advocated for diffusing the test, which often made it possible to rule out a supposed pregnancy, arguing that all physicians had to be encouraged to seize on it, even if this was in response to the woman's curiosity. 22

${ }^{20}$ For the promotion of the test: 'Un diagnostic biologique de la grossesse', La Sage-femme et le puériculteur, 10 January 1930; Louis Gernez, 'Intérêt médico-légal du diagnostic de la grossesse par les méthodes hormonales', Annales de médecine légale, November 1934; C. Simonin, 'Diagnostic histologique précoce de la grossesse', Annales de médecine légale, October 1937; Hermann Hinglais, Phénomène de Aschheim-Zondek et endocrinologie gravidique: Considérations au sujet du diagnostic hormonal de la grossesse (Paris: 1942).

${ }^{21}$ Hewitt vs Durupt, Tribunal civil de la Seine, session of 24 March 1936 (Gazette des Tribunaux, 13-17 November 1936). It is instructive to compare this case with the previous Lévy vs De Martel one: in November 1931, Dr De Martel refused to complete an operation on a fibrome because he suspected the uterus was gravid. He had immediately ordered an Aschheim-Zondek test, which proved negative. His patient, Mrs Levy, then accused him of not ordering the test in advance of the surgical procedure. The court ruled that Martel was not at fault on the grounds that, in 1931, biological diagnosis was not deemed reliable enough to be performed as a matter of routine before any invasive intervention. See Lévy vs De Martel, Tribunal civil de la Seine, session of 31 March 1936, Gazette des Tribunaux, 6-8 September 1936.

22 Louis-Vincent Martinez-Prieto, 'Du diagnostic biologique de grossesse par les méthodes spécifiques' (unpublished medical thesis: Paris, 1934). Théodore Fraenkel, 'Le diagnostic biologique de la grossesse', Marianne, 19 July 1933. In the UK, the problem was raised only after World War II. 
What about the actual extent of diagnostic practices? Evaluating these in the 1930s is made all the more challenging inasmuch as laboratories that tested for pregnancy were part of a complex constellation of public hospitals, clinical labs, private foundations (Pasteur institutes, which were at the forefront of this market) and an expanding network of almost unregulated private facilities that were either independent or annexed to clinics or pharmacies. More research is needed to better understand this heterogeneous landscape, particularly in determining the personal and institutional links between these establishments insofar as 'the success or failure of pregnancy testing hinged on whether the testers managed to cultivate a viable commercial market beyond the lab'. ${ }^{23}$ The experiments reported in scientific publications had been conducted on hundreds of individuals every year in the mid-1930s, and some observers stated that hormonal testing was in the process of becoming a common medical practice. For example, a 1936 report discussed the necessity of establishing a stock of animals in the Paris maternity clinics as a response to the substantial consumption of test rabbits. However, it is suggestive that the report referred to hospital practices. There is at least one reason to presume that this ongoing 'routinisation' was essentially limited to the medical care of seemingly abnormal pregnancies and to forensic procedures: hormonal pregnancy diagnosis featured among the most expensive laboratory services that existed. The 'Eyolma' offer cost 125 francs and the fee at the more 'select' Laboratory Cambus was 200 francs, which was the same amount as the official refund for free medical assistance. Handling and sacrificing mammals meant high costs and a small profit margin for practitioners; so it is probable that only after the adoption of the cheaper toad tests in the late 1940s did biological pregnancy diagnosis emerge as a potentially lucrative business. It therefore seems unlikely that, prior to the Second World War, pregnancy testing would have been accessible and convenient enough to attract many women unless they had serious medical issues. The price of the test and the heterogeneous access to testing facilities in France probably favoured the persistence of the usual practices of women who chose to reject a pregnancy: consuming emmenagogues or practising injections at the first sign of missed periods and, if necessary, soliciting the traditional methods or services for informing further decisions. That is probably one of the reasons why criminal abortion cases never mentioned biological diagnostics. ${ }^{24}$

\footnotetext{
23 Olszynko-Gryn, op. cit. (note 18), 234.

${ }^{24}$ Dr Canton, 'Au sujet du diagnostic biologique de grossesse', Archives de médecine et pharmacie navales, 122 (1932); Mlle C. Gutman and Jean Dalsace, 'Recherches sur la fixation de l'hormone gonadotrope dans le sérum sanguin', Comptes rendus des séances de la Société de Biologie, Paris, 118 (1935), 973-4; Concours médical, 29 December 1935; Henri Torchaussé, 'Rapport au nom de la 5e commission, sur les subventions pour études médicales', Bulletin municipal officiel de la Ville de Paris, 12 July 1936; Conseil municipal de Paris. Rapports et documents, 1937, 23 (1937); Journal Officiel de la République française. Lois et décrets, 'Tarif pharmaceutique national à l'usage de l'assistance médicale gratuite', 24 January 1924. The mean annual salary in the 1930s was around 9,000 francs. But it was only 4,000 francs for a domestic servant: Thomas Piketty, Les hauts revenus en France au XXe siècle. Inégalités et redistributions 1901-98 (Paris: Grasset, 2001), 213. It is Maurice Rives who alluded to the 'cost price' issue; see Rives, op. cit. (note 19), 11. In 1934, two doctors from the Pasteur Institute of Tangier wrote of women asking for pregnancy diagnosis for non-medical purposes: Dr P. Remlinger and Dr J. Bailly, 'Pratique du diagnostic biologique de la grossesse', Biologie médicale, 24, 10 (1934), 560-88. Léon Dérobert, in discussing Hinglais and Brindeau's talk, stated that judicial files proved that women prosecuted for abortion had hardly ever used the early tests: Annales de médecine légale, November 1945. In 1946, Dr Henri Péquignot assumed that those who refused motherhood usually managed to interrupt their pregnancy as soon as they noticed that their periods were late, in the absence of any scientific confirmation: Henri Péquignot, 'Simples remarques sur l'avortement', Archives de médecine sociale, January 1946, 175-81. This is in line with other accounts, such as: Simonin, op. cit. (note 20).
} 


\section{Early Testing and the Anti-abortion Crusade}

We next turn to the peculiar situation that occurred from the last months of 1938 (in short, after the Munich conference), through the war, and into its aftermath. After two decades characterised by the lowest fertility rate in contemporary French history, the political tensions around pregnancy were reaching a climax. However, even though the main promoters and supporters of early testing (Bar and Brindeau) were - like many leading obstetricians - notorious opponents of induced abortion, no significant criticism was voiced against biodiagnosis as a 'pre-abortion test' until December 1938. In striking contrast to contemporaneous developments in Britain, advertisers in France reframed the early biological diagnosis as an ordinary commercial service at the very moment when anti-abortion crusaders launched their strongest offensive.

\section{From Protest to Regulation}

When 'Eyolma' chose to advertise in the newspapers, the head of the laboratory had probably not anticipated that Fernand Boverat, leader of the Alliance nationale contre la dépopulation (National league against depopulation), regularly scrutinised the classifieds. Boverat was France's most determined anti-abortion activist; he investigated every notice that might be a camouflaged advertisement for abortion services, especially when the ad had been placed by a midwife. Whereas these dubious advertisements had been prohibited in 1914 and 1920, they began to flourish again in the early 1930s. It was especially in Paris - and more particularly near train stations - that these midwives were located. Immediately after he came across the Eyolma message, Boverat contacted a member of parliament and transmitted the allegedly shameful clipping to the minister of justice. Boverat was absolutely convinced that modern pregnancy tests were of interest only to women intending to procure an illegal abortion. Such dark activities, he added, justified reinforcing the anti-abortion arsenal, notably by creating special police units with the legal authorisation to search for evidence of abortions (or for unmasking abortion intentions). Their authority would be ubiquitous, including over medical and pharmaceutical establishments. ${ }^{25}$

The activist's request was taken seriously, leading to a judicial enquiry, the conclusions of which nevertheless fell short of his ambitions: the Eyolma laboratory, which performed about thirty rabbit tests every month and was headed by Eugène Arlaud, a chemist who had previously run into trouble with the law, could not technically be sued for the illegal practice of medicine, although he was not a medical doctor. Biological analyses were performed by Mrs Macus, a former assistant of the Saint-Antoine maternity ward. The laboratory's scientific protocols were unassailable. According to the public prosecutor, there was neither formal evidence of abortion-related business nor any legal means for limiting the company's activities. Designed to tackle neo-Malthusian propaganda and incitement to abortion, the Law of 31 July 1920 was in this case an impotent weapon. Nevertheless, it could help in preventing dubious advertisements, and Boverat next contacted every chief newspaper editor in Paris to demand that they purge the classifieds in compliance with the law. He further solicited the Préfet de police to request that the Paris police keep watch over suspected midwives. In spring 1939, the Alliance had not

${ }^{25}$ Fernand Boverat to the Minister of Justice, 9 December 1938, BB/18 6176, French National Archives (now 'AN'). 


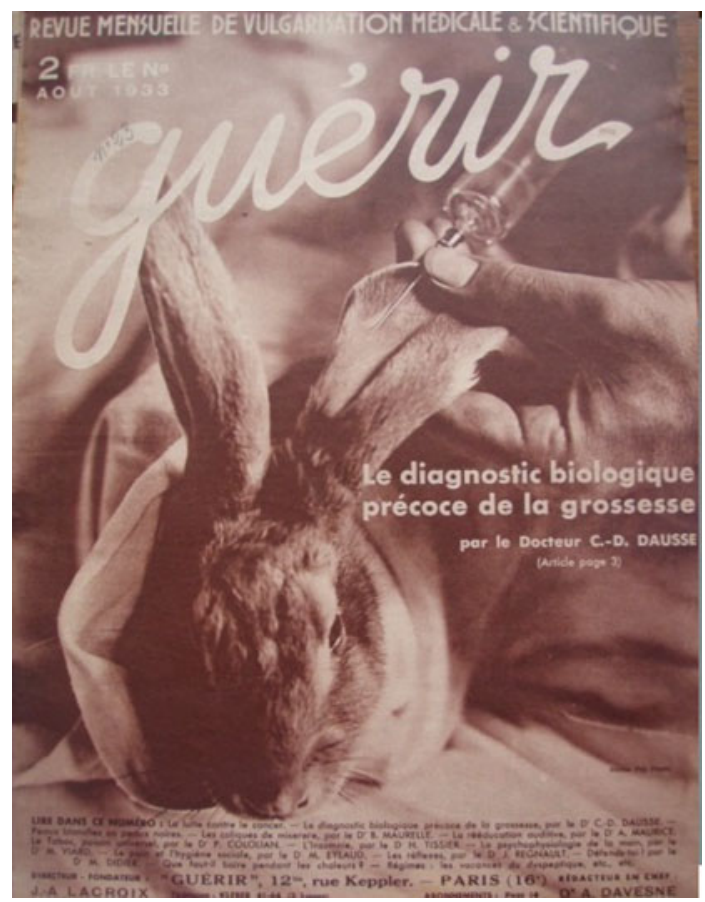

Figure 1: Hormonal diagnostic featured by a popular magazine in 1933.

managed to eliminate all ads for hormonal tests and Eyolma was still prominent in some periodicals. What is more, two issues of the popular health and medical magazine Guérir featured 'the mysteries of procreation' and praised the laboratory diagnosis of pregnancy as 'ninety-nine per cent' accurate. The splendid photo previously published on the rear cover of a 1933 issue (see figure 1) then illustrated a Cambus laboratory advertisement, which was regularly published in the magazine. ${ }^{26}$

Boverat's criticism was not unique. Octave Pasteau, a familialist Catholic physician and close relative of Pius XI who was pivotal within conservative medical movements, wrote a report on biological pregnancy testing for the Société de médecine légale (Forensic Society). This report - presented by Brindeau in January 1939 - stated that early tests offered a gateway to abortion and accused the press of publishing unacceptable advertisements. He explicitly called for a specific law to limit access to biological diagnosis. Just as with Boverat's agitations, Pasteau's intervention had a tone of moral panic and was probably based on the existence of advertisements rather than on concrete evidence of repeated abuses. Boverat and Pasteau's concerns went beyond the strict problem of the hormonal test. They felt that biological and technological innovations would not remain monopolised by 'respectable' professionals, so they aimed to maintain

\footnotetext{
${ }^{26}$ Seine departement's Substitut du procureur (deputy public prosecutor) to the procureur général (general prosecutor), 16 March 1939; Paris-Soir's chief editor to Boverat, 20 March 1939; Boverat to the Paris police prefect, 24 March 1939. These pieces come from BB/18 6176, AN. None of the newspapers stopped publishing the Eyolma ads, which - for instance - were still issued in Ce soir in April 1939. The Guérir special issues are dated 1 and 15 March 1939.
} 
the emerging (bio)medicalisation of reproduction within the narrow confines of the medical establishment. ${ }^{27}$

On 29 July 1939, the Third Republic adopted the Code de la famille de la natalité françaises. This set of statutory orders had been dictated in large part by the Alliance nationale, notably based on a report written three months earlier by Fernand Boverat. The provisions concerning abortion rigorously banned anti-pregnancy messages or connotations in advertisements. It consolidated the repressive anti-abortion arsenal by enabling the condemnation of practices on a pregnant or supposedly expectant woman. It also inserted an item on biological diagnosis, in connection with provisions about the surveillance of private health institutions and the compulsory registration of uterine curettages. According to Article 92 of the Code, completed by a Decree of 16 December 1939, pregnancy testers were required to be part of officially recognised hospitals and labs. Furthermore, they were put under dual (medical and administrative) control. Medical prescriptions were now mandatory and could not be issued by a midwife. Every test had to be reported on a nominative register that was accessible to the mayor and police. It was obligatory to provide the name and address of both the prescriber and the client, and the woman had to present her identity papers before delivering her urine sample. This latter obligation was clearly introduced to help private doctors dissuade insistent women. Furthermore, the inclusion of repressive measures increased the solemnity of the text: fraud could be punished by anywhere from three months to two years in prison and a fine of 500 to 5000 francs. In addition, courts were empowered to order the closure of any laboratory found to be in violation of the law. Finally, the statutory order was supposed to be immediately followed by an enforcement decree in order to specify the 'conditions for the opening and functioning' of laboratories and their testing modalities.

The activists, in particular the conseiller d'Etat Jacques Doublet, a member of the Alliance nationale, did their best to pressure the health administration into publishing these crucial texts. They were eventually published after consulting with the Conseil d'Etat on 18 May 1940, in the middle of the Blitzkrieg. The required conditions for heading a laboratory that practiced pregnancy diagnosis were modelled on a previous decree regulating syphilis screening, another unusually sensitive issue for diagnostic laboratories. Syphilis and pregnancy testing were therefore the only two categories of biological investigation that required a medical diploma, which implied compliance with professional norms, as controlled by the corporate organisation created by Maréchal Pétain of the Ordre des médecins. However, staff members did not necessarily have any medical status or training. New regulations established after the Liberation maintained this regime of exception. Laboratory workers were required to have graduated from university, but Wasserman tests and pregnancy diagnoses remained under a particular regime insofar as for these categories, a medical diploma was mandatory. A modification of the penal code in 1945 made it a criminal offence for any doctor to falsely certify or disclose to the authorities a disease or a pregnancy (i.e. falsified medical certificates). Under the

\footnotetext{
27 Octave Pasteau, 'A propos du diagnostic biologique de la grossesse', Annales de médecine légale, January 1939, 485-6. Boverat and Pasteau's authoritative argument was successful under the Vichy regime. In 1943, the ultra-conservative Dr Roy claimed that the 'Zondek biological reaction' had brought more evil than good: Jean Édouard Roy, L'Avortement fléau national (Paris: 1943), 275. Perreau, the author of a 'report on the works of the Toulouse Academy of Legislation', also said that it made women opt for abortion (Toulouse Academy of Legislation, 17 (1943), 90).
} 
new law, such an offence would subject the doctor to anywhere from two to ten years in prison. $^{28}$

In addition, the legal timing to notify one's pregnancy was significantly reduced. A law from August 1946, followed by several implementing decrees was - more than ever designed explicitly to oblige women to process early notification and to comply with strict medical and medico-social surveillance: the conditions for obtaining prenatal benefits mandated that the expectant mother undergo three medical examinations and a number of social visits. The first examination had to be conducted before the end of the third month of pregnancy, and this incurred notification since the doctor issued a certificate that had to be sent to the Caisse. This was far below the medico-legal threshold of 'certainty'. It is worth noting that two key experts on health and population and highly influential policy reformers of the time, Alfred Sauvy and Robert Debré, presented this requirement in the language of self-interest rightly understood: women were encouraged to know their condition early so that they could make a rational choice between (financial and in kind) protection and (financial and judicial) risk. In reality, the three-month delay primarily echoed nineteenth-century forensic statements concerning the psychological threshold after which it became less likely to attempt an abortion. ${ }^{29}$

\section{The Disillusionment of Regulation}

In November 1945, Auguste Brindeau and Hermann Hinglais presented a paper to the Société de médecine légale, which had been pivotal in a critical turn that had been affecting the anti-abortion network from within since the collapse of the Vichy government. The communication, entitled 'On the inefficiency and drawbacks of the Decree of 18 May 1940', resounded with the learned society's criticisms of the Vichy regime's repressive runaway, which they described as counter-productive and as having generated many side-effects. Brindeau and Hinglais argued that the pregnancy-test regulation had to be revised not only because the decree had proved useless, but also because it 'disturb[ed] honest medicine'. Such an excess in formalities (checking identity papers, registration and requesting a compulsory medical order even in emergency conditions) induced a high number of complicated and unpleasant situations while at the same time dangerously extending delays in receiving answers. Moreover, the over-zealous laboratories tended to

\footnotetext{
${ }^{28}$ For complementary information on the genesis of the Code de la famille: Andrés Horacio Reggiani, 'Procreating France: The Politics of Demography, 1919-45', French Historical Studies, 19, 3 (1996), 725-54; Cheryl A. Koos, 'Gender, Anti-Individualism and Nationalism: The Alliance Nationale and the Pronatalist Backlash Against the Femme Moderne, 1933-40', French Historical Studies, 19, 3 (1996). A version of Boverat's report ('Pour lutter contre la dénatalité', 9 May 1938) is kept in the F/60607 box, AN. The consecutive regulation of pregnancy testing rested on a series of legal provisions in the Journal officiel de la République française, lois et décrets: 'Décret-loi du 29 juillet 1939 relatif à la famille et à la natalité françaises', Decrees of the 16 December 1939 (pregnancy test), 29 November 1939 (syphilis screening), 18 May 1940 (pregnancy test), 29 December 1945, Law of 18 March 1946 (status and governmental approval of medical analysis laboratories and special analysis laboratories), Decrees of 18 May and 30 July 1946 (establishing a Conseil supérieur des Laboratoires d'analyses médicales). The Law of 5 May 1945 and the Order of 8 February 1945 re-insisted that false certificates were offences. The original documents I draw on here come from the F/60496 box (AN): Président du Conseil (chief of the government under the Third Republic) to the Ministry of Education, 27 January 1940; Jacques Doublet to Fernand Boverat, 4 April 1940; Minister of Public Health to Doublet, 9 April. Information pertaining to the post-Vichy period were found in: Concours médical, 20 January 1945; Dr Vidal, 'Diagnostic biologique et secret professionnel', Bulletin de l'Ordre des Médecins, 28 June 1952 session, 166-8.

29 'As soon as her pregnancy is diagnosed (and this can be done today within a short time after conception), a woman must choose between financial benefits (...) and the risks and expenses of an induced abortion' (Alfred Sauvy and Robert Debré, Des Français pour la France: le problème de la population (Paris: 1946), 183).
} 
discourage the provision of crucial information to women who were admittedly unmarried but nevertheless 'honest' and whose lives were sometimes at stake - for instance, because they presented symptoms of ectopic pregnancy. Brindeau and Hinglais further argued that the decree was senseless for three reasons. First, the decree was technically unable to prevent abortionists from buying 'a rabbit, a syringe and a needle'. Second, many non-pregnant women renounced abortion as a result of having taken the test. Third, the legal provisions failed to cover a ploy ('supercherie') - namely urine substitution - that could deceive the laboratory staff: if a woman was asked in court to confirm or deny a pregnancy, or if she wanted to convince an obstetrician that he could perform an invasive procedure involving potential abortive consequences, it was not difficult to organise such an arrangement with a relative. This fraud had already been identified by Brindeau and Hinglais in 1936 and consequently they recommended taking urine by catheter. Another reported story was that of a woman who was afraid that she was pregnant but presented herself as a happy expectant mother; by presenting a certificate dated from a previous (recent) pregnancy, she could ask for a simple, 'routine', measure of gonadotropin and thus obtain the answer she needed. ${ }^{30}$

Some members of the Conseil national de l'Ordre des médecins admitted that reform was necessary and, around 1950, asked the government to modify the regulatory framework. French physicians were as usual torn between their defence of medical confidentiality, on the one hand, and their distrust of women, on the other. This latter found particularly strong expression in the writings and practices of the most radical anti-abortion doctors. ${ }^{31}$ Based on the premise that every female patient was a potential liar, some would intentionally delay the clinical diagnosis of pregnancy if they felt a woman was reluctant to childbearing. Dr MonsaiNgeon, for instance, explained that his Catholic faith did not oblige him to tell the whole truth when it would provoke dangerous temptation. His tactic was rather to procrastinate until 'maternal conscience' was activated and it was in any case too late to attempt termination. ${ }^{32}$

These debates over the use and abuse of pregnancy testing and its regulation were part of broader deliberations. In the postwar years, several members of the Ordre des médecins dedicated themselves to a project on the codification of medical ethics. Intramural discussion had revealed a high degree of medical misconduct towards women, notably in the Vichy period, including the violation of patient confidentiality in the name of the anti-abortion fight. In his landmark treatise, A la recherche d'une éthique médicale (1954, 1964), Louis Portes, an obstetrician and former president of the Ordre des médecins,

\footnotetext{
${ }^{30}$ Brindeau and Hinglais, op. cit. (note 16). The need to prevent oneself (as a tester or physician) from deception is evoked in Brindeau and Hinglais, 'Des principales causes d'erreurs dans le diagnostic biologique de la grossesse', 8 June session, Annales de médecine légale, de criminologie et de police scientifique (1936), 419-33. The case of a woman who had brought a friend's urine sample to hide her own two-month pregnancy is reported by Meylan in Revue française de gynécologie et d'obstétrique, August 1939, quoted by Bernard Ramousse, 'De la fidélité du diagnostic biologique de la grossesse' (unpublished medical thesis: Paris, 1951). A professor named Cheymol mentioned the 'false certificate' ploy: Conseil supérieur des Laboratoires d'analyses médicales, 22 December 1948 session, 19810723/1, AN.

${ }^{31}$ Conseil national de l'Ordre des médecins, 26 April and 28 June 1950 sessions, Bulletin de l'Ordre des médecins, 91 and 166-8; letters from the Syndicat national des médecins biologistes to Conseil de l'Ordre, 27 May 1950; and from Dr Oberlin (chair of the First Section of the Conseil national de l'Ordre) to the Minister of Justice, 10 June 1950, 19950395/63, AN. Fabre and Trillat, Précis d'obstétrique, t.1, accouchement normal (Paris: 1950), 84.

32 François Chassagnard, 'Le respect du secret médical et la lutte contre l'avortement' (unpublished medical thesis: Paris, 1945), 29; André Monsaingeon, 'Le médecin devant l'avortée', in Centre d'étude Laennec, L'avortement (Paris: 1949), 50-62.
} 
sought to more precisely define the correct attitude a practitioner should adopt when faced with a pregnant or possibly pregnant patient. Whereas Portes insisted that medical values prohibited engaging in lies and obscurantism, he did not call into question the need for a doctor to be extremely cautious and vigilant. He embraced the idea that the best practices were those that protected the doctor himself, notably in cases of post-miscarriage curettage. Despite his eagerness to break with the 1940s state of mind, Portes' writings testify to prevailing suspicions against female patients. Significantly, he maintained that doctors should verify the provenance of urine samples intended for pregnancy diagnosis. ${ }^{33}$

\section{Conclusions}

In line with what has been shown regarding Britain in the decades around World War II, laboratory pregnancy testing in France was not synonymous with women's empowerment. The new technology of the Aschheim-Zondek and related tests does not seem to have been openly debated until 1938. In this year, a number of campaigners - probably alarmed by the proliferation of advertisements and perhaps by some individual cases of 'abuse' publicly denounced the laboratories that offered early pregnancy diagnosis on the grounds that they were inciting abortions. Despite the alarm, however, the evidence suggests that, in the 1930s and 1940s, biological pregnancy testing was not practised on a large scale outside a medically supervised context. Nevertheless, the small but efficient struggle against the hormonal test led to drastic legal provisions. In 1939, pregnancy testing became as regulated as the Wasserman test, a development that suggests the politicisation of social 'scourges' and moral panics. Both the law and medical recommendations restricted physicians to using the test only for medical or forensic purposes - and under the state's oversight.

The historical synchronism between decreasing the legal time limit for providing notification (especially after 1945) and regulating the pregnancy test reveals an astonishing contradiction, if not a characteristic 'double bind' (see Figure 2). Moreover, it confirms the need to reconcile and move beyond the opposing and too simplistic frameworks of 'biopower', on the one hand, and technological 'positivism', on the other. Even though early pregnancy notification was a woman's duty, the right to know was hardly unthinkable. Instead, maintaining the 'mystery' of pregnancy until the 'psychological threshold' was a (somehow desperate) means to prevent women from thoroughly selfmonitoring their reproductive activity in an efficient manner. One can nevertheless assume that a series of factors disrupted this mid-twentieth-century obscurantism: the developments of less costly, faster and more efficient toad-based testing (see Figure 3) and of the hormone-injection 'Zondek test'; the diffusion of calendar-based methods of monitoring fertility; and the spread of criticism towards the senseless and counterproductive disturbances caused by regulations on laboratory testing. Legal provisions on laboratory analyses did not change until Simone Veil's abortion law in 1975. However, because gestational information was subject less to a monolithic biopower than to the confluence of conflicting logics (morality, pronatalism, health, medicine, forensic science,

\footnotetext{
${ }^{33}$ Louis Portes, A la recherche d'une éthique médicale (Paris: 1964), 61-2.
} 


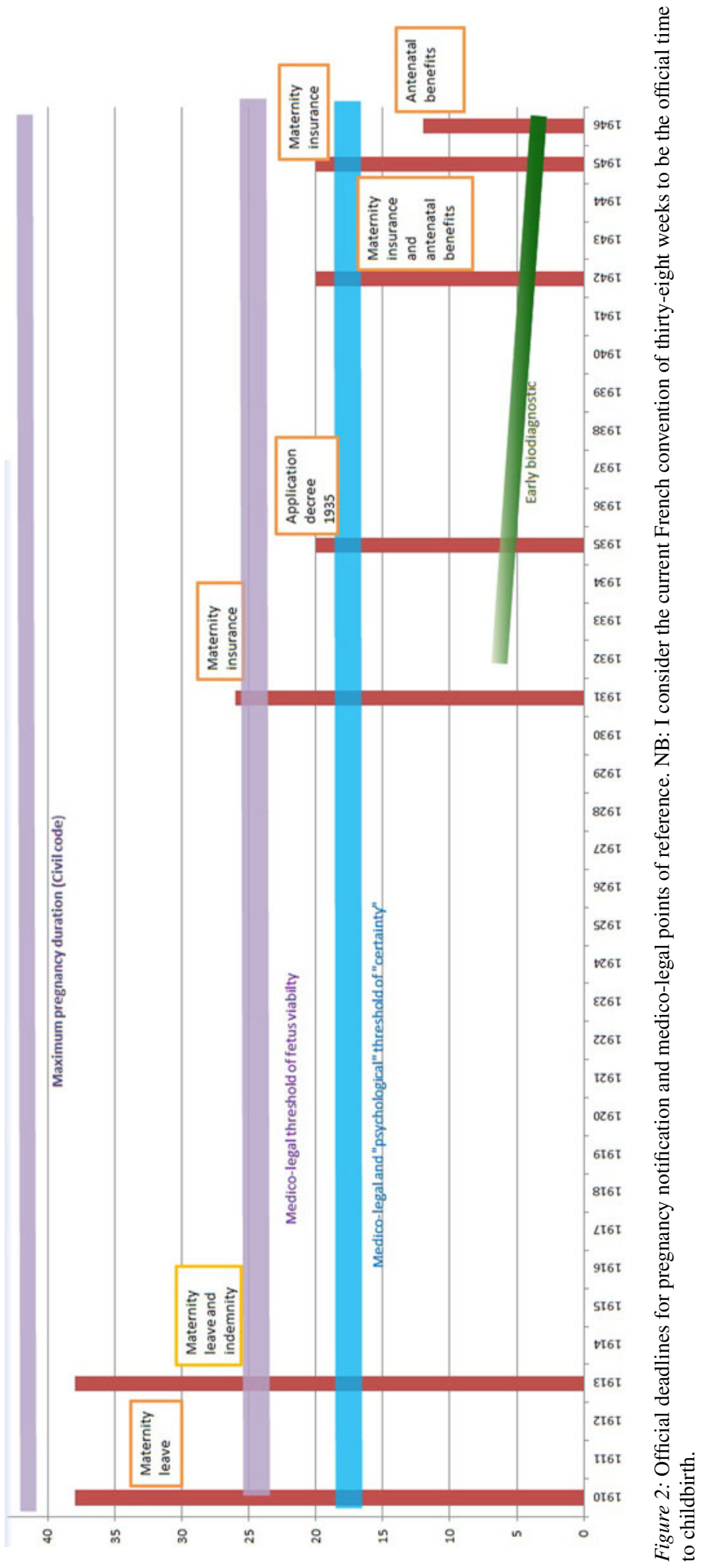




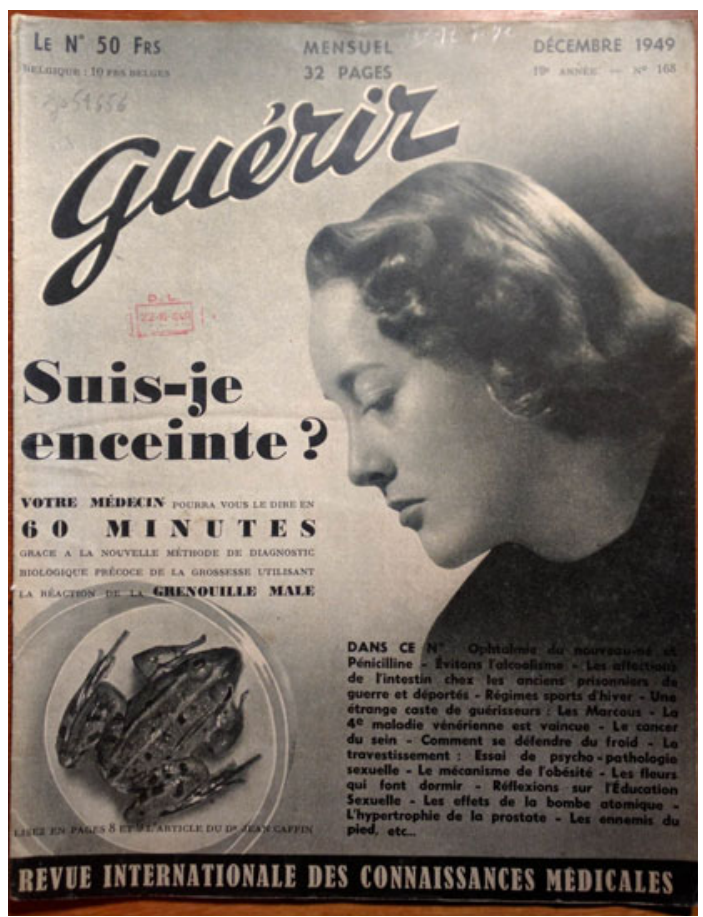

Figure 3: The frog method gives the possibility of obtaining results in 'sixty minutes'. 35

market, fertility control, and others), it became more difficult for the state to limit access to 'scientific' information after $1950 .{ }^{34}$

\footnotetext{
${ }^{34}$ After World War II, mice and rabbits were replaced by cheaper and more available frogs and Xenopus laevis toads: John B. Gurdon and Nick Hopwood, 'The Introduction of Xenopus laevis into Developmental Biology: Of Empire, Pregnancy Testing and Ribosomal Genes', International Journal of Developmental Biology, 44, 1 (2000), 43-50. Meanwhile, Zondek's experiments based on the use of sexual hormones to explain and treat abnormal menstrual cycles also had applications in pregnancy diagnosis (these aspects are studied by Cyrille Jean). The 1960s saw the development of laboratory immunoassays and the 1970s the beginning of a new era: that of home test kits. As Sarah Leavitt observed in the American context, 'The suggestion that only immoral women with something to hide would need a home kit' was expressed when this technology was made available: Sarah A. Leavitt, “'A Private Little Revolution”: The Home Pregnancy Test in American Culture', Bulletin of the History of Medicine, 80, 2 (2006): 317-45. Finally, on the use of menstrual calendars in fertility control: Martina Schlunder, 'Die Herrender Regel/n? Gynäkologen und der Menstruationskalender als Regulierungsinstrument der weiblichen Natur', in C. Borck, V. Hess, H. Schmidgen and München (eds), Maß und Eigensinn. Versuche im Anschlu $\beta$ an Georges Canguilhem (Munich: Fink, 2005), 157-95.

35 The article 'Le diagnostic biologique de la grossesse par la grenouille' ('Biological pregnancy frog diagnostic') cautions that 'the law forbids laboratories from performing pregnancy diagnostics without a medical recommendation'.
} 